\title{
舌癌の放射線治療とクライオサ一 ジェリ一の併用療法
}

\section{京都第二赤十字病院}

耳鼻科

放科

舌癌の放射線治療に減量手術の目的で,クライ オサーシェリーを併用して，治燎成果をあげ，さ らに在来の手術に比し, 形態的・機能的にす障害 を軽減し，症例によっては，放射線量をる減じ得た ので報告する。

刘照は $\mathrm{T}_{2}$ 症例 12 例, $\mathrm{T}_{1}$ 症例 1 例で, 平均 年令は 62 才（ 33 才 82 才）であった。

とのトライヤルは，昭和 49 年からで，まだ結 論を述へる段階ではないが、コバルトの外皮照射 では制禦し得なかった梁在性の $\mathrm{T}_{1} \sim 2$ 症例で クライオを併用するととにより、コントロールし 得たのである。

私達は主として，液体窒素型の装置を用い，交 換用凍結子て好んで球形のすのを試作して，圧低 法に上り用いた。これの側面を用いると，舌根部 に近い癌腫にす用いられた。

今回の症例言径が $4.0 \sim 1.5 \mathrm{~cm}$ 梁さが $2 \mathrm{~cm}$ 以下の扁平上皮癌で, 治療方法も変遷がある。ク ループ毎に代表例でその過程を述べる。

(1) 照射量 $5400 \mathrm{R}$ 以上

\section{3 才우 $\mathrm{T}_{2} \quad \mathrm{~N}_{0} \mathrm{M}_{0}$}

Co. 4500R. 照射后 Ra 針3000Rad. 㨉

入し，乙の間BLM $115 \mathrm{mg}$ を使用したが。癌 残存を認め, 繰り返し多数回のクライオを施行

して, 3 年后再発なし。クライオ使用の舌癌第 1 号。

(2) 照射量 $3600 \sim 5000 \mathrm{R}$

\section{2 才。 $\mathrm{T}_{2} \mathrm{~N}_{0} \mathrm{M}_{0}$}

C 0. 3600 R. の術前照射后, クライオ施行。 Co. 1400 Rの術後照射を加5。2 年后再発な

し。高令者に福音となった。

(3) 照射量 $3000 \mathrm{R}$ 以下

$$
\begin{aligned}
& 66 \text { 才o } \mathrm{T}_{2} \mathrm{~N}_{0} \mathrm{M}_{0} \\
& \text { Co. } 1000 \mathrm{R}+\mathrm{BLM} 7.5 m g \times 3 \text { 后クライオ。 }
\end{aligned}
$$

中村明正・岡本康比古・大州和春

長谷川 正 秀

これを3 回繰り返した。6ケ月后心不全で死亡 但し舌には癌証証明せず。

との(3)群がハイライトで 4 症例を数える。クラ イオによる減量操作を何回も行なえば,コバルト の照射量も少なくて済むてとになり，上顎癌にお ける複数回手術と放射線治療併用療法と似たるの 炕なった。

クライオは観血的手術に比し，治療日数がかつ るとか，浮僆に要注意とは云え，高令者や強い心 疾患のある患者にる影響少なく，何回す使用出来 舌機能の障害も少ないととが分った。そしてコバ ルトの外皮照射と複数回のクライオの組合せは， 各単独では果し得ないすばらしい効果をすたらし たと云えよう。

\section{質問 山際幹和 (三重大学)}

Cryonecrosis 積極的に切除されるか。( 転移を惹起する眯念の有無と関連して)

\section{答 中村明正 (京二日赤)}

ネクロトミーは 48 時間後からハサミで切っ ていをます。勿論，未凍結部まで取るわけでは ありません。

\section{質問 高橋広臣 (北里大)}

(1)気切が必要な例はないか。

(2)転移を誘発するととはないか。

答 中村明正 (京二日赤)

一回目のクライオで浮腫のをたものがありま すが，舌の後部のすのでは，あらかじめ気管切 開をしておをます。

頸部を含めて，乙の操作による転移につんて は，学者間にイエス及びノ一の二種類があるが 私の考えでは，阻血により転移し難いと思って 
います。13例中頸転移は1例のみでした。

質問 下鄉和雄 (愛知県ガンセンター)

凍結療法の際の深達度は、どの程度で, どの 位の時間を茫用してみえるか。

$1 \mathrm{~cm}$ の梁さの腫痬汇対して5〜 7 mmの梁達度 の方法をとるのは。

答 中村明正 (京二日赤)

凍結子の種類により,ワンサイクルでは 5〜 $7 \mathrm{~mm}$ が、ネクローゼになります。よって, 1. 5 cmの梁さなら 3 回の操作が必要となり，乙の間 の転移を止めるためにも、コバルト照射を続け るわけです。凍結のみの操作では，危険がある のは，卸説の通りです。 